\title{
THE SUPERWOMAN: THEORIES OF GENDER AND GENIUS IN EDWARDIAN BRITAIN*
}

\author{
LUCY DELAP \\ King's College, Cambridge
}

\begin{abstract}
This article examines the development of the idea of the 'superwoman' among British Edwardian feminists and contextualizes it within the aristocratic political thought of the day. I examine the idea of the 'genius' and the 'superman' in order to shed light on why, for some Edwardian feminists, the ideal feminist agent was to be an elite, discerning, remote figure. I argue that Edwardian feminism witnessed an 'introspective turn', marked by an interest in character, will, and personality as the key components of emancipation. The focus of political change was firmly located within women themselves. This belief was widespread, even though only a minority chose the language of the 'superwoman' to elaborate it. References to the 'superwoman' indicates the impact of Nietzschean and egoist ideas upon the women's movement. The 'superwoman' was used to position feminism as a movement not just for political rights but for wider social regeneration, and represents a characteristically Edwardian belief in the power of the 'exceptional individual' to promote social change.
\end{abstract}

The term 'feminism' first gained wide currency in Britain during the Edwardian period, and is frequently characterized as signifying a commitment to equality, inclusion, and liberal politics. ${ }^{1}$ It was, however, thoroughly contested in meaning, and recognized as significantly more radical than the more conventional grouping around 'suffragism'. 'Feminism' came to represent the views of the 'advanced' section of the women's movement, and provided a useful new ideological designation for Edwardian thinkers. ${ }^{2}$ This article examines a 'sister-term'

* I am very grateful to Deborah Thom, Sarah Tasker, Peter Mandler, and two anonymous readers, for their helpful comments and suggestions concerning this article.

${ }^{1}$ Germaine Greer in The female eunuch, for example, remarked from the perspective of the I97os on 'the faith that the suffragettes had in the existing political system and their deep desire to participate in them'. Germaine Greer, The female eunuch (London, I993), p. I4. Historian Brian Harrison sees Edwardian suffrage-feminism as dominated by the liberal agenda of Mill: 'Edwardian suffragists ... were too preoccupied with campaigning for the vote to spend much time on sketching out the shape of the new society, or on doing more than expose particular abuses and build up a following for the programme that J. S. Mill had laid down half a century before.' Brian Harrison, 'The act of militancy: violence and the suffragettes, I904-19I4', in Michael Bentley and John Stevenson, eds., Peaceable kingdom: stability and change in modern Britain (Oxford, I982), pp. 80-122.

${ }_{2}$ Nancy Cott, The grounding of modern feminism (New Haven, 1987), pp. 3-6. See also Richard J. Evans, The feminists: women's emancipation movements in Europe, America and Australasia, 1840-1920 (London, 1977), p. 39 , n. I. 
to 'feminism', one similarly fluid, and with shared connotations of 'modern' and 'progressive': the 'superwoman'. This term enjoyed a brief popularity in Britain before the First World War. A well-known militant suffragist, Teresa BillingtonGreig, proposed in I9I I that the feminist movement of the future must be 'a movement to make possible supermen and superwomen'. 3 This is a fascinating claim, and one that resists easy interpretation since the idea of the 'superman' and 'superwoman', as well as the allied concept of the 'genius', are now relatively opaque to us, despite their wide usage in Edwardian periodical and pamphlet literature. Uses of the term 'superwoman' have seldom received attention from historians. This is perhaps because, for many feminist theorists, 'superwoman' connotes an elitist, narrow ideal that seems out of keeping with feminist principles.

Historians have tended to see the fascination with the idea of genius and 'superwoman' found in the Edwardian women's movement as an aberration, clearly at odds with the feminist keystone of equality, and only of interest to isolated and marginal groups. Some have assumed that Edwardian feminists' interest in genius was motivated only by anti-feminist arguments that there were no female geniuses; feminists, it is argued, actually had little interest in imagining 'higher types' of women. Another interpretation is to see the feminist fascination with genius as itself an equality strategy. The historian Flavia Alaya argues: 'feminists seemed obliged to justify the social and political equality of women ... by proving the capacity of women to be exceptional'. ${ }^{4}$ If some women were exceptional, then all deserved political rights and social freedoms. While this may have been a strategy for some Edwardian women, it gains explanatory force through posing feminist concerns of the period in terms that are comprehensible and attractive to us a century later. The idea of equality is one we can all subscribe to. However, this attempt to reconcile elitism with egalitarianism misses an important dimension. I argue that the Edwardian belief in progress arising from exceptionality should not be read as an equality claim; the 'exceptional' individual herself was key to some feminists' hopes for social change.

This article will examine the idea of a 'superwoman' both as a concept in its own right and through the related concepts of the genius and the superman. I shall look at how the superwoman functioned as a vehicle for feminist aspirations in the Edwardian period, and what constraints it imposed on feminist thought. I argue that the idea of the superwoman captures some important features of Edwardian feminist political thought that must be recognized as co-existing with the more well-known commitments to sisterhood, inclusion, and equality. Specifically, these include elitism, introspection, and interest in internal psychological change as the first step towards external social reform. The contribution of this article, then, is to highlight some additional commitments to the political

3 Teresa Billington-Greig, The militant suffrage movement-emancipation in a hurry (London, I9II), p. 2 I3.

${ }^{4}$ Flavia Alaya, 'Victorian science and the genius of women', fournal of the History of Ideas, $3^{8}$ (1977), pp. $26 \mathrm{I}-8 \mathrm{o}$, at p. 268 , original emphasis. 
demands commonly associated with suffrage feminism. It will be my argument that ideals central to the genius and superwoman 'discourses'-ideals of character, will, and personality - were very important to many feminists of this period. These have not received much historical attention because they are difficult to incorporate into the commonly accepted narrative of twentiethcentury feminism, that equates the Edwardian period with suffragism and a 'liberal feminist' struggle for equality. In offering a new reading of Edwardian feminists' interest in genius and the 'superwoman', this article aims to contextualize the interest within contemporary political and cultural debates, and to indicate the way in which feminist thinkers engaged with self-consciously 'modern' explorations of the self. This is not to suggest that 'superwoman' was an unproblematic idea, and I conclude with an examination of its limitations and tensions.

The Edwardian debates on supermen and superwomen drew on an older language, that of 'genius'. It is useful to trace the development of ideas of genius, to show the intellectual recasting of the genius as 'superhuman' ${ }^{\mathbf{5}}$ The literature on genius in the nineteenth and early twentieth centuries was concerned with the key political questions of how society should be organized around 'greatness', and how genius could be harnessed to the needs of a race or nation. The idea of the genius as a uniquely gifted individual had become significant from the mideighteenth century, and later became a key concept of romantic thought. Genius became associated with the sublime, with lack of interest in material possessions and unconventionality. Genius status was potentially available to all, an inclusive concept to which all might aspire. It was used in progressive discourse as a concept with democratic potential, and this persisted into the nineteenth century. The genius was to act as an agent of social renewal. ${ }^{6}$ This well-known idea of romantic genius is the starting point for understanding the more elusive Edwardian concepts of genius.

In the mid- to late nineteenth century, a change in the concept of genius can be perceived, typified by the work of Francis Galton. Galton's I869 study, titled Hereditary genius, attempted to redefine genius from a universal human capacity to an embodied type, found within certain 'great' families. Genius was thus shifting from its romantic form of a broad aspirational ideal, towards a much more limited and elitist concept of individual greatness. This 'closing down' of genius can also be seen in gendered terms, in Galton's belief that 'high reputation is a pretty accurate test of high ability'. He could not allow that genius capacities might be suppressed by environment, arguing that 'if a man is gifted with vast intellectual

5 The term 'superhuman' is here used as a shorthand for the many 'super' entities (-man, -woman, -natural, -consciousness) discussed by Edwardians, though 'superhuman' was itself also a term in use.

${ }^{6}$ Howard Mumford Jones, Revolution and romanticism (Cambridge, MA, I974), and M. H. Abrams, The mirror and the lamp: romantic theory and the critical tradition (Oxford, I953). 
ability, eagerness to work and power of working, I cannot comprehend how such a man should be repressed'. The common argument from the women's movement, that women's genius existed but had been stifled, was thus ruled out; for Galton, if women were not eminent, it was definitely because of biological lack of ability. $^{7}$

Genius was also shifting from a spiritual or poetic ideal towards an empirical, measurable one. Galton's work started a trend towards empiricism in the study of genius - it could be confirmed by skull size, skin and eye colouring and so on. ${ }^{8}$ This quantification and narrowing of genius was continued into the Edwardian period by the work of Havelock Ellis. Ellis's I904 study of British genius attempted a more 'empirical' account of genius than that of Galton, based upon flows of 'mental energy' and development of the nervous system. He defined genius, somewhat vaguely, as 'a highly sensitive and complexly developed adjustment of the nervous system along special lines'. ${ }^{9}$ It took the form of 'intense cerebral energy', directed along a 'limited path'. ${ }^{10}$

Ellis was at root committed to the empirical and hereditary model of Galton. His work indicates another shift in the discourse of genius, from the unconventional, excessive romantic genius to a more conventional idea of 'eminence' by public recognition. 'Eminence', indicated through being listed in the Dictionary of national biography, gave Ellis his population of geniuses. But his concept of genius still had clear links to the constellation of ideas associated with romantic genius. Like the romantics, Ellis felt that the genius was an 'exfoliating' agent of 'life renewal', and his account of genius was associated with strong passions, imagination, the unconscious, and sexual drives. ${ }^{11}$ Sexual energy or, as it was sometimes described, 'vital force', was a successful idiom in use to describe the nebulous concept of genius; references to 'vital force', 'life force', or 'energy' are common in Edwardian descriptions of what it was to be a gifted person or a leader. ${ }^{\mathbf{2}}$

7 Galton accepted that small numbers of eminent women did exist, but could not see them as sexually attractive. He believed they would be unlikely to marry because of their 'dogmatic and selfasserting type' or their 'shy, odd manners'. This meant that their 'genius' could not be passed on, and was thus an evolutionary irrelevance. Francis Galton, Hereditary genius: an inquiry into its laws and consequences (London, I950), p. 3 I8.

8 This trend was bolstered by the empirical investigations into the distribution of genius or intelligence, such as the account published in I87I by Hyde Clarke, 'On the geographical distribution of intellectual qualities in England', Fournal of the Statistical Society of London, 34 (Sept. I87i), pp. 357-73.

${ }^{9}$ Havelock Ellis, A study of British genius (London, I904), p. 227.

${ }^{10}$ Ellis, British genius, pp. 229, 203.

11 Christine Battersby, Gender and genius: towards a feminist aesthetics (London, I989), p. I02. See also Andrew Elfenbein, Romantic genius: the prehistory of a homosexual role (New York, I999); Mumford Jones, Revolution and romanticism, chs. 9 and io. For contrasting earlier meanings of genius, see Kineret Jaffe, 'The concept of genius: its changing role in eighteenth-century French aesthetics', Fournal of the History of Ideas, 4I (I980), pp. 579-99, and Logan Pearsall Smith, Words and idioms: studies in the English language (London, I957).

12 Vitalism can loosely be described as the postulation of a 'life force' additional to mechanics or chemistry as an explanatory device in science. It had been discarded as a scientific theory for Edwardians, but remained influential as a social ideology. Edwardian vitalism gained intellectual standing through the growing influence of Samuel Butler, and the popularization of Henri Bergson. 
For Ellis, life force, and therefore genius, was closely related to sexual drive. He argued 'In men the sexual instinct is a restless source of energy which overflows into all sorts of channels', and he described creativity as 'a male secondary sexual character, in the same sense as a beard'. ${ }^{13}$ Sexual experimentation was, despite the trend to a more conventional concept of the genius as 'eminent', still a means (for men) to become a genius. The genius might be identified through his sexual promiscuity, or he might be seen to sublimate his sexual energy into his creative work.

This of course excluded women, whose sexual energy required channelling towards motherhood and care. Ellis's account of British geniuses gave a ratio of one eminent woman to every eighteen eminent men; genius was possible in women, but rare. ${ }^{14}$ Having devoted pages in his earlier study of the sexes, Man and woman, to describing women's docility, receptiveness, inattention to detail etc., he noted rather nervously: 'No inferiority is hereby attributed to women. It is perhaps even possible to attribute an equality of genius to women if we are prepared to recognise that quality outside the spheres of art and science in the wider spheres of concrete life.' Such feminine genius, he argued, was found in social work, and in love; this feminine genius was 'neither of other kind or of less perfection than masculine genius; it is merely directed on other objects', those more in line with what Ellis saw as women's natural interests. He preferred to see women's genius as complementary to the male, operating in the spheres men could not access. This was in part due to women's 'dispersal' of energy or 'vital force' through reproduction: 'The claims of reproductive and domestic life are in women too preponderant and imperious to be easily conciliated with the claims of a life of intellectual labour. ${ }^{15}$ Though sexual energy in men was closely related to genius, women's link to the sexual sphere disqualified them from genius.

'Genius' was, however, a concept in transition, and the distinction between non-genius and genius was not clearly defined for Victorians and Edwardians. Invoking gendered characteristics of genius helped to give a clearer definition to

\footnotetext{
'Vital force' was a prominent trope in the plays of G. B. Shaw and many modernist writers, and was seen as an alternative 'engine' of evolution to the survival of the fittest postulated by Darwin. Evolutionary theory had been influential in encouraging ideas of 'higher types', but seemed to rule out free will, as well as the divine element in human life. Samuel Butler argued instead that evolution was a process of 'willed adaptation to the environment', which he (and, later, Henri Bergson) referred to as 'creative evolution'. G. D. H. Cole, Samuel Butler and the way of all flesh (London, I947), p. 25; Henri Bergson, Creative evolution, trans. Arthur Mitchell (London, I9II). Creative evolution would allow humans to approach God or superhumanity, through ever increasing self-consciousness. Evolution towards higher forms was 'directed mainly by intelligent sense of need', and driven by the human qualities of ingenuity and heroism - in other words, by 'life force'. Samuel Butler, Life and habit (London, I9I6), pp. 253, 297.

${ }^{13}$ Havelock Ellis, Man and woman: a study of secondary and tertiary sexual characters (London, I934; 8th edn), p. 360 , and quoted in Alaya, Victorian science, p. 275.

${ }^{14}$ Ellis, British genius, pp. IO-II. $\quad{ }^{15}$ Ibid., pp. I58, I59.
} 
the distinction between genius and non-genius. ${ }^{16}$ Gender served as a wellrecognized dualism that could shore up less well-recognized ones. It was helpful to see vital force as a gendered entity, in order better to explain genius and giftedness. For vitalists, the male 'physico-chemical system' was 'energetic and enterprising, polemical and political'. Women's energy in contrast was (predictably) 'more emotional, more aesthetic, more domestic'. ${ }^{17}$ As Edwardian sexologists described it, femininity was 'anabolic', a preservative or 'storing' force that directed them towards reproduction. Masculinity by contrast was 'katabolic', a destructive or 'spending' force, which held the creative potential that underlay genius. ${ }^{18}$ This belief was widely held; a self-identified feminist, Millicent Murby, argued that 'the male function animates and vivifies - the female enfolds and nourishes and plays the great constructive part'. ${ }^{19}$

The significance of gender within Ellis's theory can be seen in his discussion of the 'peripheral' characteristics of genius. In A study of British genius, Ellis devoted pages to a discussion of the illnesses associated with genius - idiocy, gout, and consumption. The latter two conditions were clearly gendered: the consumptive was 'a somewhat feminine order of genius', characterized by 'their febrile activities, their restless versatility, their quick sensitiveness to impressions'. Conversely, 'the genius of the gouty group is emphatically masculine, profoundly original; these men show a massive and patient energy, which proceeds "without rest", it may be, but also "without haste", until it has dominated its task and solved its problem' ${ }^{20}$ The 'gouty genius' was presented as the more fundamental. Indeed, Ellis noted, somewhat inconsistently, that while consumption, 'by no means stands in the way of ... intellectual attainments [it] is not indeed actually favourable to mental activity' - thus marginalizing the idea of feminine genius. ${ }^{21}$

At root, Ellis's theories were based on a 'vital economy' of male sexual energy as creative. Women's life force was widely accepted to be of a conservative kind,

16 Susan Kingsley Kent's study, Gender and power, emphasizes the way in which debates about authority have frequently been cast in the languages and imagery of gender. Kent, Gender and power in Britain, I640-I99o (London, I999), p. I9.

17 R. C. Macfie, Heredity, evolution, and vitalism (Bristol, I9I2), pp. 267, 269. Macfie's theory of vitalism included a chapter-long polemical diatribe against the 'lamentable spirit of sex-antagonism so subtly inculcated by the propaganda of the so-called "feminists",

18 Patrick Geddes and Arthur Thomson, The evolution of sex (London, I889). This language was picked up in political tracts, such as that written by anti-feminist Ethel Harrison, The freedom of women (London, I908), p. 22. Cesare Lombroso, in his study of genius, had described women as 'conservators': 'Like children', he argued, 'they are notoriously misoneistic; they preserve ancient habits and customs and religions.' Cesare Lombroso, The man of genius (London, I89i), p. I38. See Alaya, Victorian science. Stanley Hall also used this distinction in his Adolescence, its psychology and its relations to physiology, anthropology, sociology, sex, crime, religion and education (New York, I904), p. 565 .

19 Millicent Murby, The common sense of the woman question (London, 1908), p. 55. Murby was involved in the translation of the I9II edition of Bergson's Creative evolution, and later contributed to The Freewoman, a feminist journal which hosted discussions of the 'superwoman'.

20 Ellis, British genius, p. I82. Gout was a 'male condition', associated with the 'choleric', defined in the rgor New English dictionary as 'A specific constitutional disease occurring in paroxysms, usually hereditary and in male subjects.' A new English dictionary, IV (Oxford, I9or).

21 Ellis, British genius, p. I8o. 
unsuitable to creative experimentation. The response to the possibility that women might claim genius through the discourses of genius on offer was to clamp down on women's aspirations through a polarized and arbitrary sexual economy and appeals to gendered 'life force'.

\section{I}

What impact did these theories of genius and 'life force' have on political thought? The shift from a universal to a more elitist idea of genius resonated with, and had perhaps informed, a turn within nineteenth- and early twentieth-century political thought towards a more aristocratic and elitist form of politics. The eminent or great individual was seen to provide leadership - national leadership, or leadership for the whole process of human evolution. Francis Galton commented: 'We know how intimately the course of events is dependent on the thoughts of a few illustrious men. ${ }^{22}$ He made it clear in his study of genius that he was trying to define the qualities of leadership that justified imperial rule by Europeans. Later thinkers saw the problem of leadership as one raised not by empire but by the move to a wider democracy. William James argued in 1907: 'Our democratic problem thus is stateable in ultra-simple terms: Who are the kind of men from whom our majorities shall take their cue?' He sought elites that would act as 'the yeast-cake for democracy's dough'. ${ }^{23}$

The fascination with elites and aristocracies is unsurprising amongst conservative thinkers who had long held that, as W. H. Mallock put it, 'the strongest human powers and the highest human faculties ... are embodied in and monopolised by a minority of exceptional men'. ${ }^{24}$ But forms of elitism were also found among progressive and radical thinkers. The 'new liberal' J. A. Hobson described the repudiation of democracy in favour of aristocracy by what he reluctantly termed 'the party of progress'. Writing in igo6, he noted: 'Nowhere have I found such great contempt for the capacity, the morals, and the power of the people as in this country. ${ }^{, 25}$ George Bernard Shaw tried to capture this convergence around the idea of aristocracy in a lecture on Ruskin's politics, which he labelled 'Tory oligarchism' or equally, 'Tory Communism '. ${ }^{26}$ John Ruskin had proposed in I86o 'the eternal superiority of some men to others, sometimes even of one man to all others'; and thus 'the advisability of appointing such persons or person to guide, to lead, or on occasion even to compel and subdue, their

22 Galton, Hereditary genius, p. 331.

${ }^{23}$ William James, The social value of the college-bred, in James, Writings, I902-19Io (New York, I987), pp. $1246-7$.

${ }^{24}$ W. H. Mallock, Aristocracy and evolution: a study of the rights, the origin and the social function of the wealthier classes (London, I898), p. 379. This was explicitly identified as a 'Tory' position by texts such as J. M. Kennedy's Tory democracy (London, I9I I), and Anthony Ludovici's A defence of aristocracy: a textbook for tories (London, I9I5).

${ }^{25}$ J. A. Hobson, 'The new aristocracy of Mr Wells', The Contemporary Review (Apr. I9o6), pp. 487-97, at p. 488 .

26 G. B. Shaw, Ruskin's politics (London, I92 I), p. $3^{\circ}$. 
inferiors' ${ }^{27}$ Ruskin did not make it clear from where this kind of leader would be drawn; others believed that it was those normally on the margins of politics who might, through their outsider status, gain special political insight. The playwright, Ibsen, an influential figure for the women's movement, believed in a version of aristocratic rule 'from below'. A statement from him formed the masthead of the ı 890 B British feminist journal Shafts:

Mere DEMOCRACY cannot solve the social question. An element of ARISTOCRACY must be introduced into our life. Of course, I do not mean the aristocracy of birth, or of the purse, or even the aristocracy of intellect. I mean the aristocracy of character, of will, of mind. That only can free us. From two groups will this aristocracy I hope for come to our people: from our WOMEN and from our WORKMEN.

The idea of the women's and working-class movements as seed-beds for a new 'aristocracy' was thus already prominent in the I8gos. Politics could serve the needs of the few, because in them were the seeds of the future, while the rest could be variously disregarded as the 'herd', 'crowd', or residuum, whose utility and fulfilment were unimportant. Alfred Orage, editor of the British periodical The New Age, summed this up in Igo7 when he argued that 'the question to be asked of every institution is whether it makes for the creation of a superior type'. ${ }^{28}$ Utilitarian concerns were scorned, and political argument centred on the evolution of a 'great society', or 'higher beings'. Many subscribed to a 'top-down' political style, believing the poor and the workers to be too volatile, or exhausted and dehumanized by their struggle for existence, to provide political leadership. The Fabians had tended to regard the poor as positively disqualified from participation: 'it is difficult for their atrophied brains to grasp an idea. Even if they could, their devitalised natures and anaemic bodies would be incapable of working for it. This explains why no socialist has or ever will come from the slums. ${ }^{, 29}$ It was not only conservatives, then, who dwelt on leadership and aristocracy. For progressives and radicals as well, leadership was crucial.

These comments capture the focus of much political and utopian thinking within 'advanced' or 'progressive' Edwardian circles. ${ }^{30}$ Innovation was to come from the front, from a few gifted individuals. Impetus for the elaboration of

${ }^{27}$ John Ruskin, 'Unto this last', in E. T. Cook and A. Wedderburn, eds., The works of John Ruskin (London, 1905), p. 74, quoted in Ernest Barker, Political thought in England from Herbert Spencer to the present day (London, I9I5), p. I93.

28 A. R. Orage, Nietzsche in outline and aphorism (Edinburgh, I907), p. $5^{\mathrm{I}}$.

29 Ruth Cavendish Bentinck, 'The point of honour: a correspondence on aristocracy and socialism', in Sally Alexander, ed., Women's fabian tracts (London, I988), p. I44. George Bernard Shaw's The illusions of socialism (London, I956) made a similar argument.

30 The content of affiliations such as 'progressive' are hard to establish for this period, one in which iconoclasm and experimentalism reigned, and the 'avant-garde' became a site of a curious mixture of radicalism and reaction. See Tom Steele, 'From gentleman to superman: Alfred Orage and aristocratic socialism', in C. Shaw and M. Chase, eds., The imagined past: history and nostalgia (Manchester, I989), pp. II2-27, and Paul Peppis, Literature, politics and the English avant-garde: nation and empire, I9OI-I9I8 (Cambridge, 2000). 
elitism amongst Edwardians can be traced to the popularization of the ideas of Max Stirner and Nietzsche. Max Stirner's The ego and his own, first published in I845, had become newly popular in English-speaking countries after the first English translation of I907. ${ }^{31}$ Stirner's key insight was that oppressive institutions were sustained through the recognition the oppressed gave to the masters and hegemonic institutions. The genius, or egoist, was the individual who did not accord such recognition. To follow one's own impulses gave one absolute freedom from oppression, and, indeed, the 'masters' were dependent upon the recognition of the 'servant'. This gave great power to the oppressed to end their state of subordination. Stirner argued 'He who, to hold his own, must count on the absence of will in others is a thing made by these others, as the master is a thing made by the servant. If submissiveness ceased, it would be over with all lordship. ${ }^{32}$

The entire focus of political change thus lay in the deployment of the 'will' and the agent's ability to self-overcome. This was a political philosophy that strongly appealed to modernist thinkers in early twentieth-century Britain, with their focus on the uniqueness and social atomism of genius figures. The idea of the genius, previously an aspirational, even democratic figure, could now be seen as the individual who threw off oppression through the cultivation of 'egoist personality'. This, as we shall see later on, was extremely significant for some feminist thinkers.

Nietzsche's popular figure of the Ubermensch was another way of articulating this idea of egoist or genius, and one with more active political connotations. While Stirner was relatively uninterested in leadership, Nietzsche's Ubermensch gave egoist morality of the 'will' a significance for his Edwardian readers that was variously interpreted in terms of leadership of the nation, the race, or humanity. ${ }^{33}$ Alfred Orage declared in I907, in highly Nietzschean terms, 'All the tragical history of man would be nothing better than a meaningless comedy were it not that such a history can be regarded as the pre-natal condition of a superior and justifying species. ${ }^{\mathbf{3 4}}$ In order to achieve this superior race, mass struggle was to be abandoned, and the focus of politics was to be internal and individualized. The nature of genius remained contested for Edwardian thinkers, but under the influence of Nietzsche and Stirner, it became more closely linked to the

31 The first British edition of Stirner's work was published in I9I2. Max Stirner, The ego and his own, trans. Steven T. Byington (London, I9I2).

32 Ibid., pp. $255^{-6 .}$

${ }^{33}$ See David Thatcher, Nietzsche in England, I890-19I4 (Toronto, I970); Dan Stone, 'An "entirely tactless Nietzschean Jew": Oscar Levy's critique of western civilisation', Fournal of Contemporary Modern History, 36 (200I), pp. 27I-92; Bruce Detwiler, Nietzsche and the politics of aristocratic radicalism (Chicago, I990). Most contemporaries drew their interpretation of Nietzsche's 'superman' or (as it was still often referred to) 'beyond-man' from Thus spake Zarathustra; see A. C. Pigou, 'The ethics of Nietzsche', and A. W. Benn, 'The morals of an immoralist: Freidrich Nietzsche. II', International fournal of Ethics, I 8 and I9 (I908 and I909). Zarathustra was one of the earliest works of Nietzsche translated into English, the first volume to be issued in what was intended to be a complete works, in F. Nietzsche, Thus spake Zarathustra: a book for all or none, trans. A. Tille (London, I896).

${ }^{34}$ Orage, Nietzsche in outline and aphorism, pp. 43-4. Also quoted in Thatcher, Nietzsche in England, p. 249 . 
introspective idea of self-overcoming - the ability to find meaning within oneself, and to recognize oneself rather than depend parasitically on others for recognition. Nietzsche's work bolstered the tendency to a more exclusive elitism in the Edwardian period. The introspective yet still democratic focus of nineteenthcentury romantic genius was combined with Nietzschean aristocracy, to form a more powerfully elitist politics of the superman. As a New Age contributor described it in I9o8,

Emerson and Carlyle [taught] that all can be supermen, individualities, representative men. Theirs is the Individualism of the Reformation preached by Luther. The Individualism of Nietzsche, however, is aristocratic. There must be ordinary men if there are to be supermen. Only the latter are the individualists. Theirs is a different morality from that of the masses. ${ }^{35}$

The genius as superman came to be a remote and even illegible figure, who had overcome weaknesses and constraints through the power of the will. This trend can be summarized by seeing Edwardian ideas of genius as politically on the cusp, between a romantic idea of the genius as a regenerative life force, to early modernist ideas of the superman as a recluse from the intolerable modern world. ${ }^{36}$ The Edwardian superman hovered uneasily between these two meanings, drawing on the unconventionality of the romantic discourse, as well as the aloofness of early modernist ideas. The romantic 'outsider' who 'exfoliated' society became what some within the progressive avant-garde termed an 'illegible authority', who turned his back on humanity. ${ }^{37}$

\section{I I}

The 'super' prefix was widely used by Edwardians, with references to 'superathletes', 'super-ladies', 'supermanity', and so on abounding in the periodical press. ${ }^{38}$ 'Superman' was a translation from the German Ubermensch, previously translated as 'over-man' or 'beyond-man'. The term became well known among Edwardians, through the popularity of Nietzsche's work and through George Bernard Shaw's adoption of the term in his 1903 play, Man and superman. ${ }^{\mathbf{3 9}}$ Shaw

35 Dr Angelo S. Rappoport, The New Age (26 Sept. I9Io), p. 429.

36 See Bruce Clarke, Dora Marsden and early modernism (Ann Arbor, I996), for further discussion of the politics and 'genius' of early modernism.

37 Barbara Will, Gertrude Stein, modermism and the problem of 'genius' (Edinburgh, 200o), pp. I-7.

38 A I92 I dictionary noted that the word 'superman' ' has led to any number of nonce formations of which the language is getting very tired'. Ernest Weekley, An etymological dictionary of modern English (London, I92I). 'Superman' and 'superwoman' were terms popular in the United States, where the Reader's guide to periodical literature listed both terms in its indices covering $1905^{-19}$, though neither term appeared before or after these dates.

39 Despite its wide usage, 'superman' was certainly not a word that gained unquestioned acceptance, and it was probably only useful to a minority of thinkers. It was described as 'a foolish word', used 'to express an ideal very popular with those to whom nature has denied a pair of shoulders and other virile attributes', Weekley, Etymological dictionary. The association between genius and homosexuality had persisted from the nineteenth century, and also permeated the idea of a superman. 
situated this as a political move: 'the need for the Superman is, in its most imperative aspect, a political one', posed by the failures of what he termed 'Proletarian Democracy' 40 The Fabian writer, Mabel Atkinson, described the superman as a 'future being in whom all the forces of life will be increased far beyond what we know now, who is to be at once harder and healthier, and more sensitive and comprehending', and who would represent 'a democracy that levels up and not down'. ${ }^{41}$ This concern with democracy was particularly important to feminists, who felt that their arguments for suffrage were vulnerable to the 'levelling down' accusation. Dora Marsden, editor of the feminist periodical The Freewoman, argued that suffragism 'has to find its defence against the criticisms which are attacking popular democracy ... [because] the immediate application of feminist ideals would bring to democracy a preponderating volume of its supposed dangers and difficulties'. ${ }^{2}$ The superman was used as utopian device, to describe a democracy of superior types, that was not threatened by the uneducated (feminized) masses. But this was a minority usage; most who used the idea of the superman took it to be an anti-democratic ideal, a means of supplementing or even bypassing democracy and constructing an aristocratic utopian order.

Two key explanations can be offered for the resonance 'the superman' had in the Edwardian period. First, it can be seen as a political and aesthetic reaction to the massification of modern life. ${ }^{43}$ There was a strong concern among Edwardians that the higher elements of life should not be swamped by the increasing influence of the masses in political and cultural life. The growth of the mass was found in a great variety of guises - in the 'yellow' press and its development of mass advertising, in urbanization, and the mass education available since $1870 .{ }^{44}$ The actual and threatened expansions of the suffrage had made a reality of mass politics. Dislike of these developments formed an element of progressive or 'advanced' thought. A representative comment comes from the liberal critic of democracy, Graham Wallas, who was anxious about the effect on politics of "working men who have passed through the standards of the elementary schools, and who live in hundreds of square miles of new, healthy, indistinguishable suburban streets' ${ }^{45}$ Wallas was part of a group of elitist liberals, many of them Fabians, who continued a trend in nineteenth-century liberalism to see democracy as incompatible with personal liberty and efficient public service. Reba Soffer has outlined this and other strands of Edwardian thought that were

40 G. B. Shaw, Man and superman (Westminster, I903), p. I96.

41 Mabel Atkinson, 'The struggle for existence in relation to morals and religion', International Fournal of Ethics, I8 (I908), pp. 29I-3II, at p. 309. Atkinson's article provides a good example of the way in which progressives used the 'superman' to frame their concerns; as a Fabian, Atkinson believed that the superman 'furnishes [Englishmen] with a motive for endeavouring politically to remedy the social conditions of to-day; for supermen cannot be bred in slums.' Ibid., p. 3IO.

${ }^{42}$ Marsden, The New Age (23 Nov. I9I I), p. 95. $\quad{ }^{43}$ See Thatcher, Nietzsche in England, pp. 272-3.

44 See John Carey, The intellectuals and the masses: pride and prejudice among the literary intelligentsia, I880-I939 (London, I992). $\quad{ }^{45}$ Graham Wallas, Human nature in politics (London, I9o8), p. 4. 
critical of mass democracy, and embraced an elitist solution. ${ }^{46}$ She describes the growth of an elitist social psychology, led by William McDougall and Wilfred Trotter, whose political aim was to declare democracy to be incompatible with the crowd instincts of human nature. ${ }^{47}$ Likewise, a critique of democracy came from the biological evolutionary thinking of Galton, Karl Pearson, and other eugenicists. These different permutations of fear of the 'mass' and its new political power made the idea of the superman popular, as a means of transcending or neutralizing the masses. The well-established literature on genius fed into this understanding of what the superman represented. Genius clearly had other meanings, and cannot be wholly elided with 'superman'. Indeed, genius had perhaps become so conventional through its association with eminence and great families that a new and more radical, inspirational agent for social change was required. The superman, then, provided a means for progressives to talk about 'superior types' in a politically neutral way, avoiding the conventionality of 'genius' and the class and 'Tory' overtones of 'aristocratic' discourse.

Second, the interest in the 'superman' was not only a political one, but also spiritual or occult. Alex Owen has traced the rising Victorian and Edwardian interest in spiritual, mystical, or esoteric philosophy and practices. ${ }^{48}$ A belief in self-transformation and inner exploration characterized many occult groups. The self that was to be explored was often characterized as multiple or fragmented, made up of many levels of consciousness, though ultimately, in contrast to psychological explorations of the self, the ego remained self-aware and controlling. ${ }^{49}$ For Owen, this preoccupation with consciousness and the self was what made the i8gos and early decades of the twentieth century 'modern'. ${ }^{\mathbf{5 0}}$ In an age marked by competing secular and spiritual claims, 'superman' may have been seen as embodying an ethical, or 'scientific' alternative to Christian faith. Bernard Shaw argued in Man and superman that life force, as the basis of all evolution, would 'build up that raw force into higher and higher individuals, the ideal individual being omnipotent, infallible, and withal completely, unilludedly selfconscious: in short, a god' ${ }^{51}$ A key assumption for many Edwardian spiritualists was the god-like nature or perfectibility of humans, expressed through the idea of the superman; Nietzsche and Henri Bergson were key influences here. Amongst

46 Reba Soffer, Ethics and society in England: the revolution in the social sciences, $1870-1914$ (Berkeley, I978).

47 Wilfred Trotter, Instincts of the herd in peace and war (London, I9i6). 'Crowd psychology' was influenced by Gustave Le Bon's The crowd: a study of the popular mind, first translated into English in I896 (London, I896). Trotter's influential book, published in I916, drew on articles published in the Sociological Review in 1908 and I9o9.

48 Owen, 'Occultism and the "modern" self in fin-de-siècle Britain', in Daunton and Rieger, eds., Meanings of modernity: Britain from the late-Victorian era to World War II (Oxford, 200I), pp. 7I-96.

49 Ibid., p. 87.

50 Owen notes the preference of I8gos thinkers for terms such as 'new', 'the modern attitude', 'extreme modernity', and 'fin de siècle' to indicate that their ideas characterized a new era. The term 'modernism' was a later invention. Ibid., p. 74.

51 Shaw, Man and superman, p. II4, also quoted in Jonathan Rose, The Edwardian temperament, I895-I9I9 (Athens, I986), p. 77. 
theosophists and members of the Hermetic Order of the Golden Dawn, the idea of the 'Superhuman', 'Higher Self', 'Permanent Self', 'Genius', or 'Perfect Man' had wide currency, and implied a new gender order. Many argued that sex would be transcended by the superman, or saw the superman as 'feminine', despite the gender dissonance this implied. Florence Farr, a member of the Golden Dawn, argued in The New Age that 'the state of consciousness, now identified by leading modern thinkers as the state called superman, is mystically feminine' ${ }^{2}$ As the theosophist writer Frances Swiney saw it, women 'are the sole means by which human evolution can proceed. Physiologically they are the most complex and highly specialised of organic forms; psychologically they are the most highly evolved.' Portraying herself as 'the prophet of the Superman', she sought 'the full and perfect development of that basic factor-motherhood - upon which the future of the race depends ${ }^{53}$ Women's role in relation to the superman, then, tended to centre on women as mothers (spiritual or physical), and this meshed with the widespread belief that women's 'vital force' or 'life force' was preservative rather than creative.

An additional connotation of 'superman' was one of breeding and racial selection. Writers spanning the political spectrum explored ideas of racial purity, degeneration, and regeneration. The Nietzschean superman, and his counterpart, the 'sub-man' provided an avant-garde means of talking about degenerates, and the need to select for a racial aristocracy. Dan Stone has charted the links between eugenicists, race theorists, and the idea of the superman, and makes a convincing case for a 'widespread acceptance of racial explanations for social and historical processes' in Edwardian Britain. ${ }^{54}$ There was, then, a racial element to this political turn towards aristocracy, though some recent historians have suggested that British racial discourse was not dominated by 'scientific rascism', but was more multifaced, working not only to construct and control racial 'others', but also to relate individuals to their past and positively shape their self-identity. ${ }^{\mathbf{5 5}}$ Degeneration and race thinking also incorporated a gender dimension. Stone notes the anxiety of such thinkers over the 'New Woman' and feminism more

${ }^{52}$ Farr, The New Age (6 June I907), p. 92. By seeing the superman as a state of mind rather than an individual, Farr was able to claim it for women.

53 Swiney in Huntly Carter, Women's suffrage and militancy: a symposium (London, I9I I), p. 63. See Lucy Bland, Banishing the beast: English feminism and sexual morality, I885-19I4 (London, I995), and George Robb, 'Eugenics, spirituality and sex differentiation in Edwardian England: the case of Frances Swiney', Journal of Women's History, ro (1998), pp. 97-1 I7.

54 Dan Stone, Breeding superman: Nietzsche, race and eugenics in Edwardian and interwar Britain (Liverpool, 2002), p. 93. Interest in race should not, however, be overstated. A representative comment in The New Age proposed a superman 'not as the offspring of male and female' but 'as self-begotten from within the mind of man'. Indeed, for this contributor, 'as an individual reaches perfection he turns instinctively away from procreation and from sex'. Anon., 'Unedited opinions', The New Age (I Dec. I9I0), p. I07.

${ }^{55}$ For both sides of the debates, see Mathew Thomson, "Savage civilisation": race, culture and mind in Britain, I898-I939', in Ernst and Harris, eds., Race, science and medicine, I70o-I969 (London, I999), pp. 235-58, and Daniel Pick, Faces of degeneration: a European disorder, c. I848-I9I8 (Cambridge, I989). 
generally; Nietzschean eugenicists such as Maximilian Mügge specifically looked for manliness as a key quality for the superman. ${ }^{56}$ As we shall see below, this perhaps made proponents of the superwoman wary of the associated vocabulary of racial degeneration, though they retained the language of spiritual or personal regeneration.

\section{V}

The superman was described by the women's suffrage journal, The Englishwoman, as 'humanity's last and noblest aspiration', and was regularly discussed by feminist thinkers interested in questions of political leadership and democracy. Given this interest in the superman from feminists, it was unsurprising that the neologism, 'superwoman' soon came into use. ${ }^{57}$ It was needed because of the strong masculine overtones of 'superman'-contemporary dictionaries explicitly pointed out that the superman was male. An early example of 'superwoman' dates from $1906{ }^{\mathbf{5 8}}$ the term became increasingly common after this, though it remained an idea only taken seriously by an avant-garde minority, and was often used as a joke, or to satirize the extravagant goals of feminism. In I9II, it was still being given a tentative status by quote marks and varying uses of capitalization, and both superman and superwoman seem to have slipped out of usage after the First World War, when what had been called the 'pseudo-superwoman' suffragette had been transformed into a voter and war worker, and 'the "super" cult, both male and female' became associated with 'the Teutonic lust of world power' and 'the Hun'. ${ }^{\mathbf{9}}$ As one commentator put it in 1917 ,

Our Superman fades before our eyes ... The war has raised the standard all round; it has shown that if our civilisation is not prolific of geniuses, it has produced a race of ordinary men and women who are braver and more generous than the dominating aristocracies and high chivalric groups of the Past. It is the answer to the scientific sentimentalists, like Nietzsche and his followers, who talk about slave-morality and crowdinstincts. ${ }^{60}$

Despite its short life, the term indicates the presence of a debate within feminism that has rarely been discussed. In part because it does not fit with our contemporary expectations of feminist principles, the twenty-first-century reader

\footnotetext{
56 Maximilian Mügge, 'Eugenics and the superman: a racial science and a racial religion', Eugenics Review, I (I909), p. I84, quoted in Stone, Breeding superman, p. 73.

57 George Robb's paper on Frances Swiney's interest in the superman misleadingly suggests that 'no English-language feminists ever used the term "superwoman" in their writings'; Robb only finds French uses of surfemme, though he accepts that many British feminists were fascinated by the idea of the superwoman. Robb, 'Eugenics, spirituality and sex differentiation', p. I8, n. I I3.

58 Westminster Gazette (22 Jan. I906), quoted in Supplement to the Oxford English dictionary (Oxford, I986).

59 'The fallibility of the term "super", Anti-Suffrage Review (Mar. I9I5), p. 22.

60 Sidney Low, 'The passing of the superman', Fortnightly Review (May I917), pp. 758, 76I.
} 
is troubled by the desire within a subsection of the feminist movement to develop a movement for superwomen, an elitist feminism that would meet the needs of 'higher types'. The formulations of superman and genius discussed above help to contextualize this interest in the superwoman, and suggest that it was very much in keeping with the political argument of the time. Victor Gollancz in his I9I7 collection on feminism argued 'The greatness of a society increases in proportion to the number of individuals who are perfectly developed'; many feminists saw it as their goal to further such a society. ${ }^{61}$ There was a surprisingly robust engagement with the question of genius within the Edwardian women's movement, despite the fact that feminine genius seemed to be entirely ruled out by biological and historical 'evidence'. ${ }^{62}$ This engagement may have been partially motivated by a desire to counter the common anti-feminist argument that there had never been a female genius. It was argued again and again that if women could not produce a single 'great' artist, poet, or composer, then they must be genuinely second-class citizens and deserved their lack of political rights. ${ }^{\mathbf{6 3}}$ In response to this, many feminist writers did not challenge the concept of genius, or try to change the terms of what counted as 'greatness'. Instead, they listed out eminent women, hitherto overlooked, who might qualify for inclusion in the conventional canon. ${ }^{64}$

But it was not only anti-suffrage arguments that explain the interest in genius and 'superwoman' displayed by the women's movement. Some were motivated by a sense that women of genius were those who felt most keenly the confines of women's position. The suffragist Helena Swanwick argued: 'the woman who suffers most [from the tyranny of conventional femininity] is the biggest woman. The world suffers too, from the stunting or warping or exasperation of its strongest and most original female minds. ${ }^{\mathbf{6 5}}$ She felt that feminism should be addressed to these exceptional women, and should organize society to meet their needs. In this context, the superwoman could stand in as a potential subject for feminist aspirations. Feminists sought to use the discourse of romantic genius, associated with the regenerative power of 'life force' and exercised by outsiders, to indicate their aim to transform society. Drawing on Nietzsche, Florence Farr argued in I9Io that the twentieth century - 'Women's Century' - was to witness 'a revaluation of all values' once woman 'awakes from her long sleep' ${ }^{\mathbf{6}}$ Feminists aimed to position feminism as a movement for social renewal; 'genius' and 'superwoman' were attractive as concepts that conveyed

61 Rathbone Royden et al., in Victor Gollancz, ed., The making of women: Oxford essays in feminism (London, I9I7), p. I3.

62 See Battersby, Gender and genius.

${ }^{63}$ See for example, Frederic Harrison's essay on 'The future of woman', in Harrison, Realities and ideals (London, I9o8), pp. 73, 74 .

64 Olive Schreiner, for example, listed Sappho and Aspasia as women of genius, but subscribed to conventional theories of genius in admitting that feminine genius was highly exceptional, Schreiner, Woman and labour (London, I978), pp. IOI-2, 87.

65 Helena Swanwick, The future of the women's movement (London, I9I3), p. I42.

66 Florence Farr, Modern woman: her intentions (London, I9Io), p. 7. 
this. This emphasis was mocked by contemporaries. The New Age journal published an epigram on 'The new genius':

With the maligned and martyred suffragette

Genius to a new note is set,

Which is, as our brave militant explains,

A great capacity for breaking panes. ${ }^{67}$

Despite such comments, writers such as Helena Swanwick sought to enlarge the spheres in which genius might operate, and thus make it more amenable to feminist ends. Swanwick focused on political rather than creative genius, and argued: 'it seems very likely that [women] have genius in directions hitherto almost forbidden to them; I mean in organisation, and leadership, and in the power to govern'. ${ }^{68}$ Feminist writers had started to think through what feminine versions of greatness and leadership would look like. Some sought to move the debate away from romantic or modernist versions of the lonely, tormented, creative genius, resisting the closing down and narrowing of the idea of genius evident in the twentieth century. Feminine genius was to look quite different, and might include such lowly, practical talents as that of organization.

In general, though, the rhetoric of the superwoman avoided such prosaic concerns, and provided a means for Edwardian feminists to signal their disinterest in the 'trivial', mass, everyday politics of the suffrage, and address feminist concerns at what was portrayed as a more fundamental level of 'self-emancipation'. This represents, I argue, an important and under-recognized element in feminist thinking of this period. An 'introspective turn' can be identified in Edwardian feminism, a desire to seek liberation not through 'externals', such as rights granted by men, but through internal transformation of one's psyche and sexual being. It was a widely accepted belief within the women's movement that ability to achieve emancipation depended on will or character. ${ }^{69}$ As Stirner had pointed out, oppressed groups such as women were themselves responsible for their position, and had to take individual responsibility for refusing to recognize the power of men. The moral tone of much late Victorian and Edwardian feminist writing was introspective and individualistic, concerned with individual character and agency. In I9ı2 Havelock Ellis approvingly wrote of the Swedish 'maternalfeminist' Ellen Key, 'She is of the opinion that the Woman's Movement will progress less by an increased aptitude to claim rights than by an increased power

\footnotetext{
67 Anon., The New Age (26 Sept. I912), p. 517. I am grateful to Tom Villis for pointing this reference out. $\quad 68$ Swanwick, The future of the women's movement, p. I47.

69 This is reflected in Olive Schreiner's Woman and labour, one of the most influential feminist works of this period. Three out of six chapters in this work are devoted to a discussion of 'parasitism', and Schreiner's emphasis is firmly on the corrupted character of women; emancipation therefore partly lay in attention to character and a determination to seize for oneself an independent lifestyle, rather than in attention to changing social institutions that impose this position on women. Charlotte Despard, president of the Women's Freedom League, made similar claims about the woman's movement and the building of character and personality. Her feminism was introspective and spiritual, but not aristocratic. Despard, Theosophy and the woman's movement (London, I9I3), pp. 34, 45.
} 
of self-development, that it is not by what they can seize, but by what they are, that women ... finally count. ${ }^{\mathbf{7 0}}$

Though gaining political rights and equality with men were important concerns, they were in some sense subordinate to women's need to exercise will and develop personality. This element of feminist thought was not exclusively tied to the interest in the elitist superwoman; for many, all women had a duty and right to self-development. Anarchist thinkers such as Emma Goldman stressed women's 'inner regeneration', while remaining highly suspicious of 'self-seeking "supermen", ${ }^{71}$ An introspective politics was not in itself necessarily 'aristocratic', and could co-exist with a desire to deepen democracy and political participation more generally.

The stress on introspection dominated the radical, 'modernist' strand of feminism and was also influential in the more conventional women's movement. The intellectual sources of this 'introspective turn' were in the 'new woman' fin-de-siècle interest in the psychological, in the more prosaic 'self-help' strand of late Victorian moral thought, which emphasized the individual's power to help him or herself, and in the egoist literature described above. The romantic ideal of self-overcoming within the 'superman' literature resonated with feminist thought. Many significant feminist (and anti-feminist) texts of this period stress women's responsibility (or inability) to overcome their weaknesses and self-imposed constraints. Otto Weininger had argued, 'Who is the enemy? What are the retarding influences? The greatest, the one enemy of the emancipation of women is woman herself. ${ }^{72}$ Within The Englishwoman, a contributor argued 'not until [women] have learned ardently to despise the ignoble, and to desire as ardently the higher man will the superman be more than the "baseless fabric of a vision", ${ }^{73}$

The debate over 'superwomen' did not, in general, run along racial lines. It may be that race was not discussed because it was an assumed element of the discourse, given its prevalence within Edwardian political argument more widely. But the absence of a strongly racialized 'superwoman' discourse seems worthy of comment, given the racial and degeneration rhetoric pervading British debates about aristocracy and elites. Feminist thinkers such as Frances Swiney certainly made some claims about 'Teutonic womanhood', and sporadic calls for 'white women to fight now' against Jewish domination are found within the women's movement. Such claims may have been particularly prevalent among mystical and occult elaborations of 'superwoman' ${ }^{74}$ The anti-Semitism of the women's movement was widespread, and has been mostly overlooked by historians. But in broader usage, the concept of the superwoman seems relatively race-neutral.

70 Ellis, introduction to Ellen Key's The woman movement, trans. M. B. Borthwick (London, I9I2), p. xv. Key's maternalist policies placed her on the conservative side of the women's movement.

71 Emma Goldman, 'The tragedy of women's emancipation', in Anarchism and other essays (New York, I969), p. 230, and Alix K. Shulman, ed., Red Emma speaks (London, I979), p. 89.

${ }^{72}$ Otto Weininger, Sex and character (London, I906), p. 45.

73 Ethel L. Rogers, 'The professor, women and the superman', The Englishwoman (Nov. I9o9), p. 24.

74 Schreiner, Woman and labour, p. I44; Farr, Modern woman, p. 8. 
Perhaps it was conceptually so remarkable to change the gender of the superhuman ideal that race was simply eclipsed. Alternatively, feminists may have been aware that their claims about women's emancipation were blamed for racial degeneration, and they therefore avoided adopting this language. They preferred to construe 'the woman question' as, above all, of feminine character, and it seems that these concerns of character and personality were not located within degenerationist debates. The emphasis was on women's own power to bring on the age of the superman or superwoman.

This question of character reveals a different set of concerns to those normally associated with the predominant suffrage-feminism of the period. Rights were frequently not sought as ends in themselves, but as tools to self-development. As Charlotte Carmichael Stopes, the mother of Marie Stopes, described it in I9I I, the strongest argument for the vote was in terms of internal change for women, followed by external action by, and not on behalf of, women. The vote would help women 'to develop our individuality, to perform our duty, to fulfill our responsibility'. ${ }^{75}$ Another commentator described the vote as likely to be 'a staggering blow' to women convinced that they were the inferior sex. ${ }^{76}$ Not all were convinced that the vote would do women any good, and some argued that it might retard their personal self-development by making them clients of a bureaucratic political system. Above all, women's personality or character was key to their emancipation.

Of all Edwardian feminist sources, The Freewoman periodical of IgII to I9I2 epitomizes this primary emphasis on changing oneself allied to a (contested) commitment to leadership by elites. Subtitled 'a weekly feminist review', this was the first British periodical to call itself 'feminist', though it rapidly adopted 'humanist' and 'individualist' as alternative affiliations, and some of the more prominent of its small circle of contributors came to reject the 'feminist' identity. Though it reached a tiny readership, the journal briefly gained a very high national profile, and was notorious for its frank discussions of sexuality and emancipation beyond the vote. The journal's editor argued that its project lay in enabling British feminism to become 'definitely self-conscious and introspective' ${ }^{77}$ Freewoman contributors tended to regard women as the great obstacle to their own emancipation and preached the necessity for internal psychological change. Only geniuses or superwomen were likely to be able to achieve this. As a

75 Stopes, in Carter, Women's suffrage and militancy, p. 57. $\quad{ }^{76}$ Clifford Sharp, in ibid., p. 48.

77 The Freewoman (henceforth $F W$ ) (23 Nov. I9II), p. 3. The Freewoman amplified the demand for self-development, while rejecting the focus on service and duty that was another strong feature of Edwardian feminism, and is reflected in Stopes's comment. On The Freewoman, see Les Garner, A brave and beautiful spirit: Dora Marsden, I882-I96o (Aldershot, I990); Clarke, Dora Marsden; Lucy Delap, 'The Freewoman, periodical communities and the feminist reading public', Princeton University Library Chronicle, 6I (2000), pp. 233-76; Lucy Delap, "Philosophical vacuity and political ineptitude": The Freewoman's critique of the suffrage movement', Women's History Review, I I (2002), pp. 6I3-30; Lesley A. Hall, 'Stella Browne, the new woman as freewoman', in Angelique Richardson and Chris Willis, eds., The new woman in fiction and in fact: fin-de-siecle feminisms (Basingstoke, 200I). 
contemporary critic put it, "the superwoman is the ultimate expression of that new philosophy of feminism preached by the daring "humanist" review, the London Freewoman'. ${ }^{78}$ One editor, Dora Marsden, specified that 'only those women who are gifted to the extent of genius can be Freewomen, and all the rest must be Bondwomen, i.e., followers, servants' ${ }^{79}$ Another editor, Mary Gawthorpe, idealized the 'aristocratic perfect self-mastery of True Man'.80 Contributors felt that modern conditions of 'mass-values' worked against genius. One, Charles Whitby, bemoaned 'the sacrifice of the great to the small, the exceptional to the mediocre, the superman and superwoman to the manikins of both sexes ' ${ }^{81}$ Whitby pointed out 'the wretched life of the typical man of genius' under the current democratic and utilitarian politics of mass-values, and argued instead that 'those for whom [happiness] is synonymous with ecstasy shall set the tune of life'. ${ }^{82}$ Another, Françoise Lafitte, described her feminism as motivated by 'the comedy of superman toppling over underwoman'. She had come to believe in the motto: 'no common good without grand individuals', and this had led her to The Freewoman group. ${ }^{83}$

The Freewoman's stance was based upon a passionate and spiritual ideal of genius, sometimes expressed as the 'superwoman', sometimes as the 'freewoman'. Since the journal was independent and committed neither to suffrage nor democracy, it could consider radically elitist or inegalitarian political orders. The content of The Freewoman was saturated with the idea of 'great personality'. As the editor, Dora Marsden put it, 'Moral institutions are dissolved, not by the multitude, but by the higher moral consciousness of the few. A handful of moral, thinking, articulate freewomen are more than a multitude of the unmoral, inarticulate bond. In these things the battle is decided by rank and not by numbers. ${ }^{\text {'84 }}$

So how could women free themselves of their internal psychological constraints? According to Marsden, nothing but 'the sense that she is a superior, a master can give her the strength [to become a freewoman]' ${ }^{85}$ Though she accepted that some external conditions had to be met, she was vastly more interested in the internal question of genius. If one had genius, one could undertake the hard and solitary process of self-transformation. The insight that Freewoman contributors had gained from Max Stirner was that women's recognition of male power - epitomized in their request for the vote and equality - could only shore up this power. Making requests of men implied servility; women should rather seize what they wanted on an individual basis. The power of change lay with the enslaved, who could simply refuse to accord recognition to male institutions. It was the superwoman, independent and self-confident, who might achieve this

78 Current Opinion (Jan. I9I3), p. 47, Dora Marsden Collection, Manuscripts Division, Department of Rare Books and Special Collections, Princeton University Library box IV folder 2.

${ }^{79}$ Marsden, $F W$ (3o Nov. I9II), p. 2I. $\quad{ }^{80}$ Gawthorpe, The New Age (I2 Sept. 1912), p. 479.

81 Whitby, $F W$ (I8 Apr. I9I2), pp. 425-6. ${ }^{82}$ Ibid.

${ }^{83}$ Françoise Delisle, Friendship's odyssey (London, I946), pp. I80-I.

84 Marsden, $F W$ (I8 July I9I2), p. I64. $\quad{ }^{85}$ Marsden, $F W(23$ Nov. I9II), p. 2. 
mode of political emancipation, and thus served as an aspirational model for some Edwardian feminists. As one Freewoman contributor put it, woman was destined 'to realize in herself the highest and best of which humanity is capable; to become in the dim distance of time a being higher in type than man and further removed from the animal, physically, mentally and morally'. ${ }^{86}$

It was not only egoist philosophy that contributed to this distinctive discourse of emancipation. As described above, theosophy was also an important influence, although one of which most Freewoman contributors were extremely critical. ${ }^{87}$ None the less, theosophists and other spiritualists had opened up a new space for thinking through the nature of the self, for both practitioners and critics. ${ }^{88}$ Freewoman readers were also interested in the ideas of Havelock Ellis, Otto Weininger, and other 'sex psychologists', as well as psychology more generally. ${ }^{89}$ Two Freewoman contributors, Barbara Low and David Eder, became prominent psychoanalytic practitioners, with Eder providing some early translations of Freud, and from 1912, experimenting in psychoanalytic methods. ${ }^{90}$ The development of Edwardian psychology, and, after igII, early readings of Freudian psychoanalysis, was part of the intense interest in the nature of the 'modern self' that contextualizes the interest in superman and superwoman. Psychology provided a language and conceptual framework for the Edwardian 'introspective turn', by calling into question the rational, conscious individual. This was discussed in The Freewoman in relation to aspects of women's mental and physical life, including the prison and hunger strike experiences of suffragists, and women's sexual experiences. The language of 'new psychology' gave expression to the desire among feminists to explore new stages of mental evolution, beyond consciousness or representing a higher consciousness appropriate to the modern 'super-world'. Psychologists' undermining of the unitary self, however, made this discourse less suitable for those who wanted to explore the 'superhuman', since this was usually understood as implying a self-aware, transcendent, and 'perfected' individual consciousness, rather than a fragmented one.

Introspection became allied to elitism in the debates around who could qualify as a superwoman. Marsden defined genius as 'an individual and personal vision of life in any sphere'. This somewhat vague definition was not intended to set up a broadly available and accessible concept of genius. She pointed out that 'great numbers of individuals are born without any creative power in regard to any

${ }^{86}$ E. M. White, International fournal of Ethics, 22 (Apr. I9I2), pp. $32 \mathrm{I}-34$, at p. 334 .

${ }^{87}$ See comments from Dora Marsden in a letter to Harriet Shaw Weaver, 2 Sept. I9I3, Shaw Weaver papers, vol. 57352, British Library.

88 Mathew Thomson, 'Psychology and the "consciousness of modernity" in early twentiethcentury Britain', in Daunton and Rieger, eds., Meanings of modernity, pp. 97-II5.

89 Ellis subscribed to the journal and his wife, Edith Ellis, addressed the Freewoman Discussion Circle that met fortnightly in London. See Bland, Banishing the beast, for a fuller account of this interchange between feminism and sex psychology.

${ }^{90}$ In I9I3 Eder became the first secretary to the London Psycho-Analytic Society. See J. B. Hobman, David Eder: memoirs of a modern pioneer (London, I945). 
sphere of life whatever'. The reader was reminded that 'not for one moment do we wish to support the view that all women will be free, any more than all men are free ... a feminist must make her appeal to freewomen, and not to "ordinary" women'. ${ }^{91}$ The 'equality strategy' that has been used to explain feminists' interest in genius was not in evidence. Instead, there was a belief that feminism must be led from the front, and should not be associated with the mediocrity introduced into politics by a wider democratic franchise, the 'votes for women' demand.

There was a concession towards broader access to the realm of the superhuman, however. As Havelock Ellis had emphasized, it was considered possible to achieve higher states of consciousness or being through the power of sexuality. It was an important aspect of the Freewoman project to throw off the respectability and sexual conservatism that suffrage feminists predominantly favoured. Fearful of anti-feminist comments about licentiousness and sexual disorder, few Edwardian suffragists were willing to risk their cause by commenting on women's sexuality, and preferred to emphasize women's civic responsibilities as mothers and workers. In contrast, the Freewoman version of the feminist-superwoman emphasized the power of sexual experimentation to allow a transcendence of the ordinary spheres of life; sexual energy, akin to vital force, was perceived as 'the democratic passion' which was 'within the reach of all' as a 'means of springing life higher'. ${ }^{\mathbf{2}}$ The superwoman thus fluctuated between an inherent 'superior type', marked off from the herd once and for all, and an embodied, sensual state of being that was accessible to all who chose to experiment with their sexuality. This latter view drew on the discourse of 'vital force' as an explanation of achieving 'genius', but attempted to turn this away from an interest only in male creativity, towards a view of sexuality jointly giving men and women access to higher realms. One Freewoman contributor commented that 'the sex instinct flows into aesthetic expression which is by no means connected with the production of children'.93

Freewoman reader Helena Swanwick recognized in her I9I3 book on the future of the women's movement that arguments about genius and vital force needed to move on from the portrayal of women as mothers. She accepted that motherhood and genius were probably incompatible, not due to any draining away of "vital force' in women, but for the more pragmatic reason that genius required 'intense egotism' and concentration, and these were likely to be unavailable to the mother. However, she declared: 'This does not dismay me at all. Why, after all, should the genius be a mother? And if she be, could she not find motherly women to bring up the children? ${ }^{\mathbf{9 4}}$ It was a novel feature of Edwardian feminism that it was accepted that not all women would or could become mothers. This opened the door to imagining other forms of achievement, in creative and leadership

91 Marsden, $F W(30$ Nov. i9i I), p. 2I.

92 Marsden, $F W(23$ May i9I2), p. 2.

93 'A.B.', $F W$ (I Feb. I9I2), p. 213, also quoted in Lucy Bland, 'Heterosexuality, feminism and The Freewoman journal in early twentieth-century England', Women's History Review, 4 (I995), pp. $5^{-23}$, n. 22. 94 Swanwick, The future of the women's movement. 
roles. Some feminists could argue, as Edith Browne had in The Freewoman, that motherhood was 'the ruin of intellect and individuality'.95 Other Freewoman contributors could imagine a future in which men and women would share childcare, and mothering was therefore not the end of a woman's individual aspirations. ${ }^{96}$

\section{$\mathrm{V}$}

Thus far, I have indicated the sources within the intellectual and political milieu of this interest in the superwoman - the widespread discussions of the 'superman' and interest in Stirner and Nietzsche, and the exploration of new ideas about the self and consciousness within psychology and spiritualist groups. But the experiences and practices of suffragism also contributed. One of the chief motivations for this interest in a superior elite of women was Freewoman contributors' experiences of the militant suffrage movement. Many had been or still were members of the Women's Social and Political Union (WSPU) or Women's Freedom League, and both initial Freewoman editors had been arrested and imprisoned for 'the cause'. Militant groups can be seen as both influenced by the shift towards 'aristocratic politics', and yet working in ways antagonistic to it. The aristocratic politics described above strongly emphasized the difference a few, committed individuals could make to the course of events, and one of the attractions of militant action to Edwardian women was such a belief in the political impact of the few. The few would redeem the many, and the complete commitment of a select elite was preferred to mass politics. Moreover, the embrace of violent direct action could also be seen as a means of self-transformation. In overcoming timidity and the norms of feminine passivity, one might move closer to the ideal of the transcendent superwoman.

This power of militancy to create 'superwomen' was compromised, however, by the organizational demands of the suffrage groups. The militant movement had served to crush the sense of self-worth and individuality that direct action might have developed, by demanding absolute obedience and self-subordination from its followers. As Freewoman contributors pointed out, activists were required to act in a disciplined, regulated manner that allowed for no discovery of personal 'genius'. Furthermore, militant suffragists continued to deploy the very discourses of femininity that governed the internalized subordination of women - the appeals to self-sacrifice, and to femininity expressed in attractive dress and charming manners. It was Dora Marsden's disgust at these constraints, particularly those imposed on her ability to intervene autonomously and directly in the struggle, that led her to quit the WSPU and establish The Freewoman. Militant action had first led her to believe in her own powers of intervention in politics, and then crushed her hopes. She and other contributors resented the internalization of the

95 Edith A. Browne, $F W$ (I I Jan. I912), pp. I53-5, at p. I54.

${ }^{96}$ Watson, $F W$ (I4 Apr. I9I2), p. 397; Dennett, $F W$ (9 May I9I2), p. 499. 
psyche of obedient 'follower' and thus gained an interest in self-transforming 'superwomen'. Some writers for The Freewoman came to adopt an anti-democratic stance, arguing against the vote and portraying democratic representation as a device to engender servility and 'mass values'. ${ }^{97}$ Marsden concluded: 'It is a contemptible weakness on the part of the intelligent to suffer themselves to be made insignificant under the wide-spreading robes of the stupid. ${ }^{, 98}$

Yet even among the small community of Freewoman contributors, there was no consensus about what 'superwoman' meant. Some rejected it altogether, arguing 'If freedom can only be attained by an infinitely small number of "SuperWomen", it seems to me hardly worth fighting for at all. ${ }^{\mathbf{9 9}}$ Some felt that their stress on elites was compatible with democracy. A utopian group, the Angel Club, argued that their 'overman' was not like the 'atavistic' overman of Nietzsche, but something more akin to Confucian or even Christian morality. They concluded 'We can be a true democracy only on condition that we are a true aristocracy', and sought a childless community, dedicated to the service of genius. ${ }^{\mathbf{1 0 0}}$ Others felt that while they might agree with the politics of the superwoman, they themselves could not qualify. One reader asked the editor to 'grade the aspiring freewomen into classes; then I might, perhaps, scrape into the last one by the skin of my teeth. It is so bitter to feel that one hasn't even a sporting chance of ever being free. ${ }^{\text {'101 }}$ The concept of the superwoman was self-consciously exclusive, and was a site of anxiety for Freewoman contributors. Many were clearly apprehensive at the thought of being measured and found wanting according to a standard of feminine genius. Some were also critical, however, of the underpinning assumptions of egoism - the idea that the superhuman, creative individual suffered no external constraints, could voluntarily declare him or herself free, and had no material constraints seemed to imply that someone else, likely to be a woman, would meet their material, bodily needs. A Freewoman contributor argued in a letter to the editor: 'One wonders how far the artist would work out his conceptions if he did not depend on the services of his fellows. Would he realise his soul if some one did not do the menial work? ... You frequently speak of the artist. Would you wish each of us to be an artist? ${ }^{102}$

She perceived the carelessness concerning the subordination of others that was at the heart of The Freewoman's attraction to the idea of genius. There was a fundamental tension between the claims of the many over the few in the concept of a superwoman, a tension that reflected the ambiguity of the concept between the more inclusive romantic agent of renewal and the modernist aloof and transcendent genius.

\footnotetext{
97 See Delap, Philosophical vacuity, pp. 61 3 -30.

98 Marsden, $F W($ (18 Jan. I9I2), p. I62.

99 E. M. Watson, $F W(2$ I Dec. I9II), p. 9I.

100 'The Chancellor', 'The angel club', New Freewoman (I Oct. I9I3), p. I44.

101 Helen Hamilton, $F W$ (2 I Mar. I9I2), p. $35^{2}$.

102 Rachel Graham, $F W\left(5\right.$ Sept. I9I2), pp. 31 $3^{-14}$.
} 
We have seen how preoccupied Edwardian political thinkers were with the impact of the few and the great. This concern was expressed within The Freewoman, in the belief that the best feminist strategy was to concentrate on the gifted few, to encourage them to fulfil their potential, and thus perhaps to lead the way to a broader female emancipation. What lay at the heart of this method was the belief that the constraints on women were mainly internal. External constraints existed, but the real problem was internalized within women. For Marsden, freewomen 'declare themselves free by acting as freewomen' ${ }^{103}$ A fellow paper, The Forum, saw this as the most distinctive feature of this periodical:

The Freewoman came with the incredible heresy that the woman movement was nothing if not an effort on the part of the women to lift themselves forever out of the 'servant' class and to place themselves definitely and finally among the 'masters' using their faculties, like all masters, for the upbuilding and development of their own personalities and the advancement of their own personal aims. ${ }^{104}$

Though presented as a heresy, this belief in self-overcoming was in fact very much in keeping with Edwardian political thought, including that of the feminist movement. The discourse of genius offered an ideal language to discuss the voluntaristic process of self-overcoming that many Edwardian feminists identified as emancipation. The genius was the paradigm example of the perfectly individualized ego, succeeding through self-motivation and will. Yet how useful was this? At a conceptual level, 'genius' resisted feminist deployment. Gender was such a keystone in the concept of genius that it was very hard to change its gender connotations. Feminist attempts to rethink and broaden the concept of genius were very partial, and failed to establish firmly the idea of feminine genius.

The prevailing exclusivity of early twentieth-century conceptions of genius and the 'superman' made theories of feminine genius, and the 'superwoman', troubling. Though women were paradigm outsiders and thus seemed to fit the bill for romantic genius, they could not instantiate elite leadership. In fact, they represented the mass and the vulgar, the very features of modern society that the superman was to transcend. ${ }^{\mathbf{1 0 5}}$ Their agitation to achieve suffrage and freedom to work only emphasized this - they were no longer content with an individualized existence as the 'angel in the home', but sought to join the public sphere 'en masse' as workers and voters. The superman's self-transformation was premised on the devaluation of the mass or the crowd figured as female. The social psychologist Gustave Le Bon had notoriously argued 'Crowds are everywhere distinguished by feminine characteristics.' He elaborated that the mass was marked by those features - 'impulsiveness, irritability, incapacity to reason, the

\footnotetext{
103 Marsden, $F W$ (I6 May I9I2), p. 504.

104 The Forum, Oct. I912, p. 457, Dora Marsden Collection, Princeton University Library folder IV,

105 Andreas Huyssen, 'Mass culture as woman: modernism's other', in After the great divide: modermism, mass culture and postmodernism (London, I986), pp. 44-62, at p. 55 .
} box 2 . 
absence of judgement and of the critical spirit, the exaggeration of sentiments, and others besides - which are almost always observed in beings belonging to inferior forms of evolution - in women, savages and children'. ${ }^{\mathbf{1 0 6}}$ Women were widely believed to cluster around the average, to be more invariable than men, lacking the great heights and depths of achievement. As the American psychologist Stanley Hall argued, 'Women go in flocks, and in social matters are less prone to stand out with salient individuality.' But Hall's overall opinion was that women could only be mothers of supermen and not to aspire to superhumanity themselves. ${ }^{107}$

As a gendered entity, genius and its underlying ideas of 'life force' could not be appropriated for feminist purposes without some tensions. Though a Freewoman contributor described feminism as 'in essentials, an expansion of the life-force', the trend of the Edwardian concept of genius persisted in seeing 'feminine' life force as reproductive and conservative. ${ }^{108}$ Orage commented in The New Age: 'the mystical idea of the emancipation of women is not unlike the mystical idea of the transfiguration of man into superman. In both instances there is a conquest not by suppression but by illumination of the sex nature which humans share with the animals.' This was a veiled reference to women's mothering capacities. For Orage, it was more in keeping with women's 'natural genius and instincts, if instead of attempting to better men in industry, ... they were ambitious enough to attempt to become better women than Eve!'. As a result, 'men would become more manly as women became more womanly' ${ }^{109}$ Stanley Hall's conclusion that women were 'at the top of the human curve from which the higher super-man of the future is to evolve' sounded promising for the evolution of great women, even 'superwomen'. But in fact, in Hall's opinion, woman could only mother the superman, and not aspire to superhumanity herself. ${ }^{110}$

This emphasis on mothering gained ground amongst feminists themselves. In I9Io a contributor to The Nineteenth Century saw the confidence to bring an illegitimate child into the world as the very mark of a superwoman, and in I9I5 American feminist Charlotte Perkins Gilman wrote of an aristocracy of 'Over Mothers' in her utopian novel, Herland. ${ }^{111}$ A somewhat self-satisfied tone of celebration of women's maternal role came to increasing prominence within

\footnotetext{
106 Le Bon, The crowd, pp. 21, I7.

107 Hall, Adolescence, p. 5 6r. See also Kopald, in Frida Kirchway, ed., Our changing morality: a symposium (London, I925).

108 M. P. Willcocks, FW (I8 July I9I2), p. I75. The Freewoman group disintegrated as the journal moved away from feminism and became more firmly 'high modernist' under its new title, The Egoist. Dora Marsden sought solitary philosophical self-realization, became a recluse, and eventually her mental health broke down under the strain. See Garner, Brave and beautiful spirit.

109 Orage, 'Notes of the week', The New Age (22 Aug. 1912), pp. 385-9, at p. 389.

110 Hall, Adolescence, p. $5^{6}$ I.

111 Margaret L. Woods, 'Supermanity and the superwoman', Nineteenth Century, 66 (igio), p. 534. Charlotte Perkins Gilman, Herland (New York, I970), p. 69. Gilman had previously celebrated genius in terms of the 'domestic genius' and 'mother-genius' of women, 'Genius, domestic and maternal', Forerunner (July I9Io), pp. 5-7.
} 
later Edwardian feminism, both in arguments for the vote and in portrayals of women's role as citizens. Maude Royden, active within the National Union of Women's Suffrage Societies, agreed with the theorists of genius who argued that women were ineligible due to their 'wastage' of life force on reproduction. In I9I7 she argued:

We have all a certain vital force, which seeks expression in creation. Some of us have very little, or find life gives it no scope. Some have a force like Niagara, and like Leonardo da Vinci, pour it in torrents along the ways of action, poetry, art. Women's vital force can, and generally does, pour itself into motherhood. Fatherhood costs much less, and the force spent leaves much to spend elsewhere. I think, therefore, that there will always be more 'creators' among men than among women in art, literature, and science. ${ }^{112}$

Women's genius, for Royden, was predominantly in the realm of care, and her feminism was concerned with the revaluation of this realm. Royden's stance was that which gained most support in later decades, as the focus of the feminism shifted from the pre-war stress on personality and introspection to post-war campaigns for family allowances. ${ }^{113}$ It is not surprising, then, that the political discourse associated with superwoman should have become less useful to feminist purposes, as the attention of many after the igi 8 suffrage victory turned to supporting and protecting mothers.

'The superwoman' emerged as an unstable amalgamation of a romantic agent of social renewal, tied to a modernist sense of exclusivity and withdrawal. I have argued that 'genius' and the 'superhuman' seemed to offer some tempting features for feminists, and progressives more widely - specifically, they offered a (relatively) politically neutral means of talking about leadership and aristocracy. But with regard to gender it was not neutral at all, and was not amenable to successful appropriation by feminists. Genius was understood through the gendered metaphors of vital force. The superwoman was constituted by the Nietzschean, elitist discourse, wherein women represented the vulgar and servile masses. Any attempt to offer a feminine version of the superman without systematically challenging the gendered discourse of genius and superhumanity was not likely to succeed. The feminist ideal of the superwoman provided an enigmatic and confining intellectual framework through which to conceive of women's emancipation.

\footnotetext{
112 Royden, in Gollancz, ed., The making of women, p. 50. For typical view on women, genius, and vital force, see Ellis, British genius, pp. I58, I59.

113 See Eleanor Rathbone, The disinherited family (London, I924).
} 